\title{
Estrogen and estrogen receptors in the modulation of gastrointestinal epithelial secretion
}

\author{
Xin Yang ${ }^{1}$, Yanjun Guo ${ }^{1}$, Jialin He ${ }^{1}$, Fenglian Zhang ${ }^{1}$, Xuemei Sun ${ }^{1}$, Shiming Yang ${ }^{1}$ \\ and Hui Dong ${ }^{1,2}$ \\ ${ }^{1}$ Department of Gastroenterology, Xinqiao Hospital, Third Military Medical University, Chongqing, P.R. China \\ ${ }^{2}$ Division of Gastroenterology, Department of Medicine, School of Medicine, University of California, San Diego, California, \\ USA
}

Correspondence to: Hui Dong, email: h_uidong@163.com

Keywords: estrogen, estrogen receptors, $\mathrm{HCO}_{3}^{-}$secretion, $\mathrm{Cl}^{-}$secretion

Received: April 15, 2017

Accepted: May 22, 2017

Published: May 31, 2017

Copyright: Yang et al. This is an open-access article distributed under the terms of the Creative Commons Attribution License 3.0 (CC BY 3.0), which permits unrestricted use, distribution, and reproduction in any medium, provided the original author and source are credited.

\section{ABSTRACT}

Gastrointestinal (GI) epithelial ion transport is physiologically important in many aspects of humans, such as in maintaining fluid balance of whole body, and also plays a role in the development and progression of common GI disease. Estrogen and estrogen receptors have been shown to modulate the activity of epithelial ion secretion in GI tract. This review aims to address the current state of knowledge about the role of estrogen and estrogen receptors in modulation of GI epithelial secretion and to elucidate the underlying mechanisms. We highlight the recent findings regarding the importance of estrogen and estrogen receptors in GI epithelia protection and body fluid balance by modulation of gastrointestinal epithelial $\mathrm{HCO}_{3}{ }^{-}$ and $\mathrm{Cl}^{-}$secretion, especially current information about the regulatory mechanisms of duodenal $\mathrm{HCO}_{3}{ }^{-}$secretion based on our study in this field. Since there are no reviews on this topic but only few papers to address the main issues, we hope to timely provide new perspectives for the association between estrogen and GI disease.

\section{INTRODUCTION}

Gastrointestinal (GI) tract secretion plays a critical role in maintaining systemic liquid balance and the progression of several common diseases. Specifically, human $\mathrm{GI}$ mucosal $\mathrm{HCO}_{3}{ }^{-}$secretion protects $\mathrm{GI}$ epithelia against acid-peptic injury. Generally, women suffer less life-threatening and chronic illnesses than men, such as cardio(cerebro)vascular diseases, certain cancers, chronic fibrogenic disorders (atherosclerosis, renal and liver fibrosis), and emphysema [1]. Compared with age-adjusted men, women have lower mortality rates for the 15 leading causes of death [2]. It has been reported over the years that $17 \mathrm{~b}$-estradiol (E2) plays a role in maintaining the systemic electrolytes and liquid homeostasis [3-6]. The extra-gonadal effects of estrogen on GI secretions are female-specific and are both genomic and rapid 'non-genomic' cell signaling patterns. In GI, the regulation of estrogen in ion channels and transporters appears to have beneficial impact. However, the emergence of the targets and molecular mechanisms related to this modulation is only in the last decade $[7,8]$.

Although we are on the stage of understanding estrogen role in GI ion transport in general and the effects in health and disease, much rapid estrogen responses in GI is remained to be revealed in the underlying physiological and molecular mechanisms, especially, in the sexual difference in extra-gonadal influence of estrogen on ion channels and transporters. In this review, we highlight the recent findings regarding estrogen in GI secretion, especially intestinal epithelial $\mathrm{HCO}_{3}{ }_{3}^{-}$secretion based on our study in this field, and hope to provide an insight into the current state of estrogen modulation of GI epithelial secretion and the underlying mechanisms as promising areas for clinical application. 


\section{Estrogen in GI}

Estrogens are steroid hormones synthesized in all vertebrates and produced primarily in the reproductive tissues, such as corpus luteum, ovarian follicles and placenta. They are also produced in smaller amount in the non-reproductive tissues, such as breast, liver, adrenal gland, fat tissue and GI as well [9]. There are three types of physiological estrogens: estrone (E1), $17 \beta$-estradiol (E2) and estriol (E3). E2 is the most active estrogen, which has profound effects on the growth, differentiation, and function of many reproductive and non-reproductive tissues [9-11]. And it is the primary female reproductive hormone and plays a biological role in target tissues by regulating the transcriptional and cell signaling processes [9]. There is an emerging field of research in the modulation of estrogen in the physiology of non-reproductive tissue. The prominence of absorptive and secretory epithelia among the list of E2 target tissues suggests an important role of estrogen in the regulation of ion transport processes to adjust the body electrolyte and liquid balance $[6,12]$.

Classically, E2 has been thought to play its role through a genomic mechanism, which mainly combines estrogen with nuclear estrogen receptors and then regulates transcription. The genomic mechanism needs several hours for the effects to be shown as the time required to transcribe and translate estrogen-regulated genes [13]. Nevertheless, rapid responses of E2 found in several cellular systems can't be classified as a genomic mechanism [14-16]. So these rapid effects were defined as 'non-genomic' effects of estrogen [17]. The non-genomic action of estrogen can activate a series of intracellular second messengers rapidly, with potential seconds to minutes in different cells, by interacting with plasma membrane receptors [14-16].

Ueyama et al. reported that E2 levels in the portal vein were much higher than those in arterial blood, and that the main estrogen was determined as E2 with gas chromatography [18]. They also showed the presence of estrogen synthetase, aromatase or cytochrome P450arom in gastric parietal cells. Gastric E2 is synthesized from progesterone via androstenedione and testosterone by enzyme reactions of $17 \alpha$-hydroxylase (EC: 4.1.2.30), 17ß-hydroxysteroid dehydrogenase type 3 (EC: 1.1.1.62) and aromatase (EC: 1.14.14.1), respectively [19]. Thus, a relatively large amount of E2 is synthesized in gastric parietal cells.

As long as gender differences are concerned, sex hormones have been usually considered as the cause factors. For example, many studies have indicated estrogen as a protective role in the development of various diseases, including cardiovascular diseases [20-22], cerebral damage and mortality [23, 24], endometriosis $[27,28]$ and osteoporosis $[25,26]$. Interestingly, in GI, epidemiological studies have also turned out that men have a higher prevalence of peptic ulcer disease than women [29-32], while women taking estrogen-containing oral contraceptive pills or pregnant women exhibit a further reduced frequency of duodenal ulcer [33]. In contrast to ulcer disease, female gender, but not oral contraceptive use, was reported as a risk factor for ulcerative colitis relapse [34]. Overall, it is reasonable to infer that, E2 may have protective effects in the GI tract similar to other organs.

\section{Estrogen receptors in GI}

Estrogens exert their effects via diffusion through the plasma membrane and signaling through hormonespecific estrogen receptors, which are also expressed in the brain, kidney, sweat gland as well as in the respiratory tract [35]. Estrogen receptor (ER $\alpha)$ was first cloned from a human breast cancer cell line in 1986 [36]. Ten years later, a second ER was cloned from rat prostate [37], which was named as ER $\beta$. Most of E2 have their effect through these two nuclear ERs, ER $\alpha$ and ER $\beta$, members of the nuclear receptor super family, which regulate both unique and overlapping physiological effects of E2 [13]. The two nuclear ERs, exhibit distinct transcriptional properties and can form both homodimers and heterodimers [38-40]. In addition, nuclear ERs can sequestrate other DNA-binding proteins as to regulate gene expression in the nucleoplasm.

To add the complexity, a membrane G-protein coupled receptor, GPR30 (or GPER1) has been proposed as an alternative estrogen-binding protein [41, 42]. The first identified alternative estrogen receptor molecularly is GPR30 [41, 43]. In 2000, Filardo et al. first suggested that GPR30 might play a role in the effect of estrogen. They reported that in a breast cancer cell line SKBR3, which only expresses GPR30 but not ER $\alpha / \beta$, E2 activates Erk-1/2. A few years later, Thomas et al. showed that E2 was an endogenous ligand for GPR30 located at the plasma membrane [41]. In a quest to better understand the mechanisms, a table and a complex web of estrogen with multiple estrogen receptors signaling has been uncovered, and novel location for estrogen receptor and novel rapid crosstalk with other cellular signaling pathways (Table 1, Figure 1) [44]. It is possible that there are a number of receptors signaling from multiple locations in one cell to give an integrated cellular response to estrogen.

The two isoforms of the estrogen receptor, ER $\alpha$ and ER $\beta$, show marked differential tissue expression and biological roles. ER $\alpha$ is predominantly expressed in breast, uterus, vagina and other tissue types [45, 46]. $\mathrm{ER} \beta$ is predominantly found in ovary, testis, spleen, lung, hypothalamus and thymus with some expression noted in breast tissue [46]. In 2012, a large Chinese cohort study confirmed the existence of $\mathrm{ER} \alpha$ and $\mathrm{ER} \beta$ in both gastric cancer and non-cancer tissues [47]. Recently, Fan Zhou et al. confirmed the presence of $\operatorname{ER} \alpha$ and $\operatorname{ER} \beta$ in stomach by immunohistochemistry [48]. Most of the studies on ERs in GI tract focus on gastric and colonic 
Table 1: Basic characteristics of two classes of estrogen receptors

\begin{tabular}{|c|c|c|}
\hline \multicolumn{2}{|c|}{ ESTROGEN RECEPTORS } \\
\hline Receptor group & Intracellular receptors & $\begin{array}{c}\text { Rhodopsin-like family of seven- } \\
\text { transmembrane G } \\
\text { protein-coupled receptors }\end{array}$ \\
\hline Example & ER $\alpha, \mathrm{ER} \beta$ & GPR30 \\
\hline Localization & Cytosol, Nucleus & $\begin{array}{c}\text { Plasma membrane, } \\
\text { Endoplasmic reticulum }\end{array}$ \\
\hline Signaling pathway & Genomic & Non-genomic \\
\hline Ligand & $17 \beta$-Estradiol (E2) & $17 \beta$-Estradiol (E2) \\
\hline
\end{tabular}

ER, estrogen receptor; GPR30, G protein-coupled receptor 30.

cancers, but their expression and function are little known in human normal intestinal epithelia. In 2011, our team demonstrated for the first time ER expression in human proximal duodenal mucosae by Western blot analysis and immunohistochemistry. Both ER $\alpha$ and ER $\beta$ proteins are expressed at similar levels in the duodenal mucosae of healthy male and female young volunteers and also in mucosal epithelial cells. Of note, in duodenal mucosa, ERs mainly expressed in the cytomembrane and cytosol of the villous and crypt cells [49].

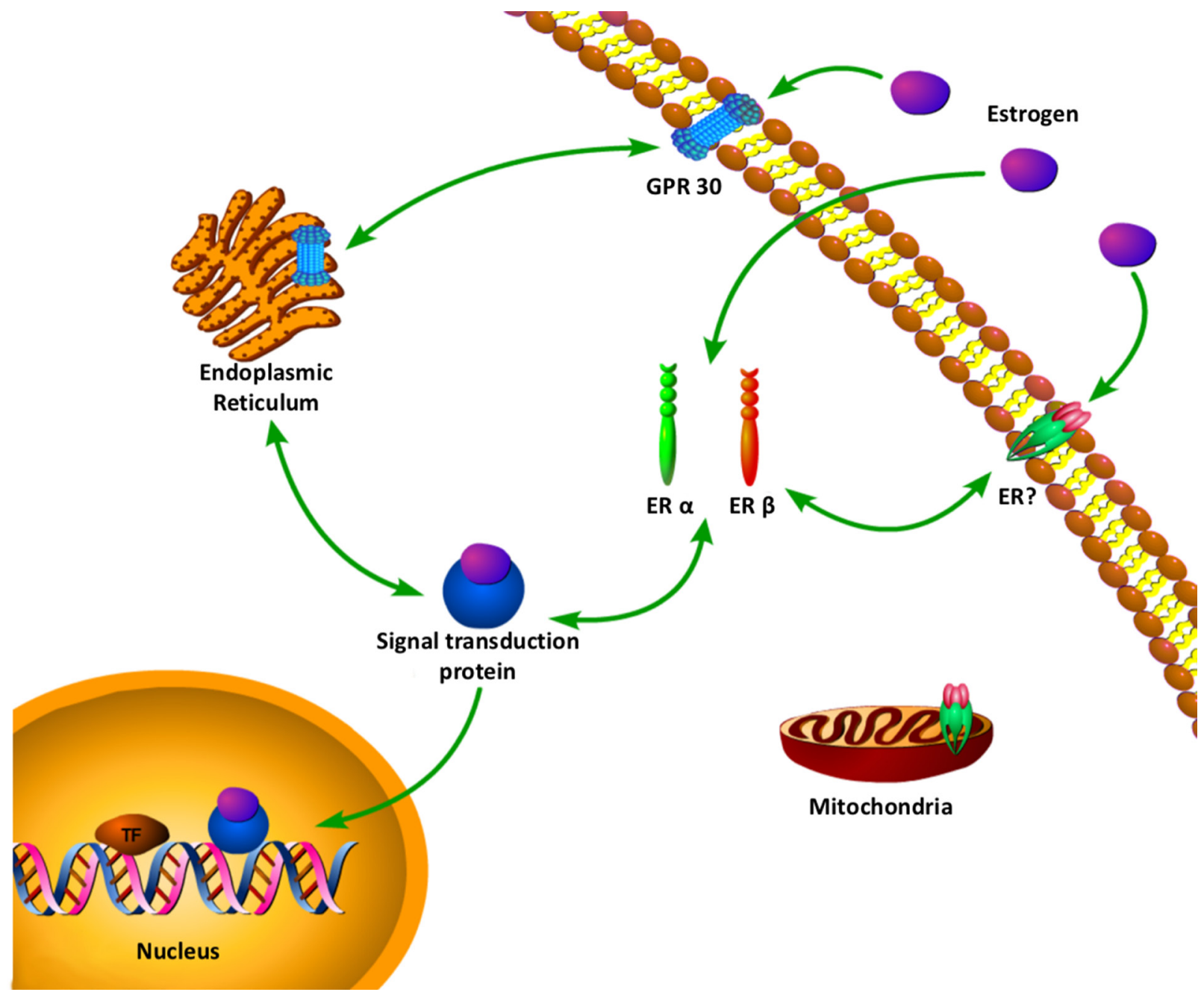

Figure 1: A complex web of estrogen with multiple estrogen receptors signaling has been uncovered. Novel location for estrogen receptor and novel rapid crosstalk with other cellular signaling pathways. ER $\alpha$, Estrogen receptor $\alpha$; ER $\beta$, Estrogen receptor $\beta$; ERE, Estrogen response element; GPR30, G protein-coupled receptor 30. 


\section{Modulation of $\mathrm{HCO}_{3}^{-}$secretion}

A century ago, Russian physiologist Vasilii Boldyreff has described the ability of GI tract to selfregulate luminal acidity [56]. Between the surface epithelium and the acidic lumen can form a $\mathrm{pH}$ gradient in chambered gastric or duodenal mucosa in vitro [57-59]. The gastric and duodenal mucosal $\mathrm{HCO}_{3}{ }^{-}$secretion was one of the main reason caused the $\mathrm{pH}$ gradient, which was recognized in the 1970s [60-62]. Gastric and duodenal destruction caused by acid and pepsin are called peptic ulcers (including gastric and duodenal ulcers). Peptic ulcers occur when the balance between aggressive and defensive factors is disrupted. While GI mucosal $\mathrm{HCO}_{3}$ secretion makes great effort in GI mucosal protection against acid-induced injury $[63,64]$. The proximal duodenal mucosal $\mathrm{HCO}_{3}^{-}$secretion is significantly diminished in patients with duodenal ulcer compared to healthy volunteers, which indicates that reduced $\mathrm{HCO}_{3}$ secretion plays a role in the pathogenesis of duodenal ulcer [65]. Men suffer duodenal ulcer more often than women. The ratio of male/female in the incidence of duodenal ulcer is 1.9:1 in the United States, 2.2:1 in Europe, and 3.6:1 in China [31, 66, 67]. It suggests that differences between the sexes in duodenal ulcer is likely caused by female sex hormones. Estrogen was shown to prevent peptic ulcer in animals $[68,69]$, but the mechanisms remain unclear.

Among the pathophysiologic abnormalities in duodenal ulcer vary in frequency, the decreasing of duodenal mucosal $\mathrm{HCO}_{3}^{-}$secretion is the most common factor as it protects duodenum against acid-peptic damage. In 2007, we found that basal and acid-stimulated duodenal mucosal $\mathrm{HCO}_{3}^{-}$secretion responses were 1.5 and 2.4fold higher respectively in female than male mice in vivo [70]. So our team hypothesized that estrogen stimulates duodenal mucosal $\mathrm{HCO}_{3}{ }^{-}$secretion. And we found E2 and also the selective ER agonists of ER $\alpha$ and ER $\beta$, rather than progesterone, stimulated murine duodenal mucosal $\mathrm{HCO}_{3}^{-}$secretion. E2 can stimulate murine duodenal mucosal $\mathrm{HCO}_{3}^{-}$secretion in both genders, while it has 4.3-fold higher responses in female than in male mice. But neither ER $\alpha$ nor ER $\beta$ mRNA and protein expression levels differed according to gender. Our data showed that E2 linked to intracellular calcium, cystic fibrosis transmembrane conductance regulator(CFTR) and $\mathrm{Cl}^{-} /$ $\mathrm{HCO}_{3}^{-}$anion exchanger to stimulate $\mathrm{HCO}_{3}^{-}$secretion. It confirmed the differences of the duodenal mucosal $\mathrm{HCO}_{3}$ secretion between the sexes in duodenal in mice. And we first found that estrogen stimulated more murine duodenal mucosal $\mathrm{HCO}_{3}^{-}$secretion in female than male mice, which may attribute to the lower incidence of duodenal ulcer of clinically observation in premenopausal women than the age-matched men.

In 2011, our experiments conducted an epidemiological investigation on the correlation duodenal ulcer prevalence with sex and age [49]. Proximal duodenal mucosal $\mathrm{HCO}_{3}^{-}$secretion was measured from healthy subjects. We found that the prevalence of duodenal ulcer was significantly lower among women than among men. The greatest reduced prevalence occurred between premenopausal women (20-49 years) and age-matched men, which were 3.91-5.09 fold, while among subjects 60 years or older the difference was reduced to $\leq 1.32$ fold. Premenopausal (20-29 years), but not post-menopausal (60-69 years) women, had significantly higher basal and acid-stimulated duodenal mucosal $\mathrm{HCO}_{3}^{-}$secretion than the age-matched men. However, both ER $\alpha$ and ER $\beta$ proteins were expressed at similar levels in the duodenal mucosae of healthy male and female volunteers (20-29 years) by Western blot analysis. It demonstrated that estrogen is beneficial to duodenal ulcer in human beings clinically, but the underlying mechanisms are not explored.

Prostaglandins are important mediators of normal physiology. They are members of a family of lipid mediators derived from cyclooxygenase-mediated metabolism of arachidonic acid [71, 72]. Prostaglandin E2 (PGE2), which is distributed widely in the GI tract, can regulate a variety of gastrointestinal functions and is the most important intra-mucosal mediator of acid-stimulated duodenal mucosal $\mathrm{HCO}_{3}^{-}$secretion in human beings $[73,74]$. PGE2 could increase cAMP production and activate protein kinase $\mathrm{A}(\mathrm{PKA})$ that directly stimulates CFTR. And PKA can also phosphorylate IP3 receptors to sensitize them to basal levels of IP3, which could improve IP3 receptor response and enhance $\mathrm{Ca}^{2+}$ release from the intracellular stores [75]. In 2012, we found that E2 (at the physiological concentration 1nM) and PGE2 additively increased phosphatidylinositol 3-kinase(PI3K) activity and Akt phosphorylation [76]. And the specific PI3K inhibitor, Wortmannin, can inhibite estrogen-potentiated PGE2stimulated duodenal mucosal $\mathrm{HCO}_{3}^{-}$secretion and Isc with Ussing Chamber. In conclusion, Estrogen enhances PGE2stimulated duodenal mucosal $\mathrm{HCO}_{3}{ }^{-}$secretion through the activation of ER $\alpha$ and the cAMP and PI3K-dependent mechanism as Figure 2, which may account to the lower prevalence of duodenal ulcer in young women.

In addition, in 2015 , Karim $\mathrm{K}$ et al. wanted to elucidate mechanisms underlying differential effects of these hormones on uterine $\mathrm{pH}$. They found high expression of CAII, III, XII, and XIII under the influence of progesterone and estrogen plus progesterone could contribute to the decrease of uterine tissue and fluid $\mathrm{pH}$ [77]. However, whether individual estrogen can influence the significance of high levels of CAIX expression remains unclear. And in 2016, Hai Jin1 et al. found endogenous estrogen upregulated the expression and functional activation of CFTR and $\mathrm{Cl}^{-} / \mathrm{HCO}_{3}^{-}$anion exchanger SLC26A6 in duodenal mucosa [70]. All these suggested novel mechanisms of estrogen in regulating $\mathrm{HCO}_{3}{ }^{-}$transport. 


\section{Modulation of $\mathrm{Cl}^{-}$secretion}

For water conservation, the distal colon is the important site in the human body. The ion transport across the epithelium, especially the $\mathrm{Na}^{+}$and $\mathrm{Cl}^{-}$transport, determines the rate of water loss and recovery from the lumen of the colon. Distal colon has been accounted as a target tissue for E2; indeed both ER $\alpha$ and $\mathrm{ER} \beta$ were detected in colonic crypts [78].

In 2001, Brian J. Harvey laboratory first described that estrogen inhibits epithelial $\mathrm{Cl}^{-}$secretion of the female distal colon [14]. They found that the activity of $\mathrm{K}^{+}$channel was suppressed after treated with estrogen at physiological levels. The anti-secretory action of estrogen is different between males and females according to the ion transporter protein expression profile. Then in 2011, they found that E2 reduced the currents with Ussing chamber mediated by the KCNQ1:KCNE3 potassium channel rather than KCNQ1:KCNE1 or KCNQ1 alone [79]. And they further revealed that E2 inhibited of intestinal mucosal $\mathrm{Cl}^{-}$secretion induced by enterotoxins [80]. In 2013, Harvey BJ and his colleagues found that E2 can regulate the abundance of KCNQ1 on cell membrane by endocytosis. This study has demonstrated for the first time of hormonal regulation of KCNQ1 trafficking [81, 82]. However, it is unclear if $\mathrm{E} 2$ induces this anti-secretory effect via a specific activation of ER, and if so, what subtypes of ERs are involved.
In conclusion, these researches revealed that estrogen physiologically regulated $\mathrm{Cl}^{-}$secretion and contributed to the observed E2-induced water and salt retention during the high estrogen states [83]. As Brian J. Harvey laboratory has published several reviews on their work of this part [77, 84], we just describe briefly here.

\section{Clinical implications}

Estrogens, the primary female sex hormones, were originally characterized through their important role in sexual maturation and reproduction. However, emerging evidence suggests a clinical association between estrogen/ estrogen receptors and GI disease, which is certainly an under investigated topic.

Several clinically relevant in vivo models showed that selective stimulation of ER $\alpha$ is sufficient to elicit many biological responses contributed to estrogen action [50-52]. When ER $\beta$ agonists were administered to rats with inflammatory bowel disease (IBD), the symptoms of chronic diarrhea were reversed, and intestinal inflammation was reduced [53, 54]. And in 2014, Kumral $\mathrm{ZN}$ et al. demonstrated the possible protective effects of $\mathrm{ER} \alpha$ and ER $\beta$ subtypes in the pathogenesis of colonic and gastric oxidant damage [55]. In the colitis and ulcer groups, both ER agonists and the non-selective E2 reversed the oxidative damage in a similar manner. These findings indicate that estrogen acts through both ER $\alpha$ and

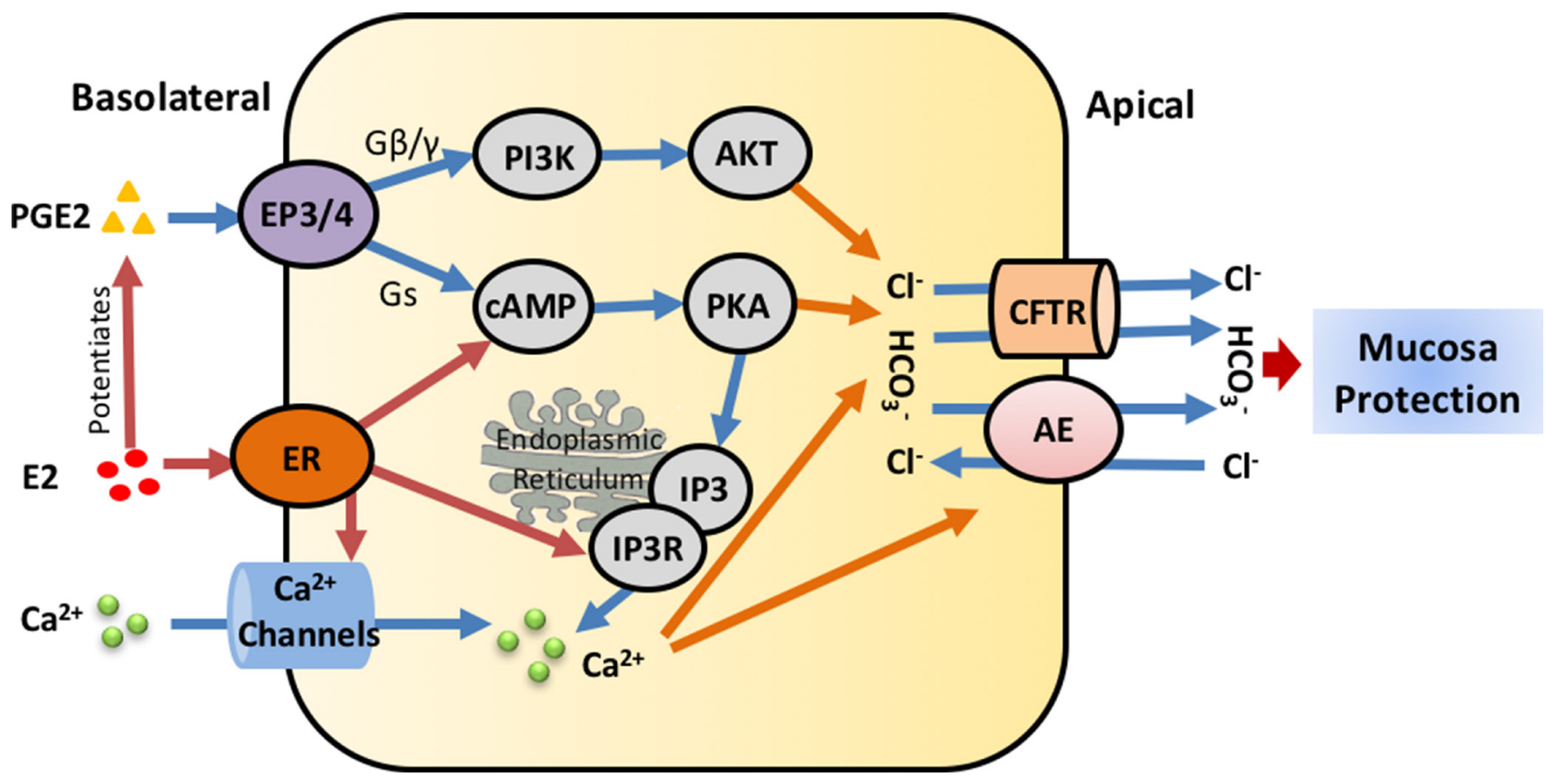

Figure 2: Regulatory mechanisms of estrogen/estrogen receptors on intestinal epithelial ion transports. In the duodenal mucosa, estrogen either directly stimulates ER-mediated or potentiates PGE2-mediated epithelial ion transports through Ca ${ }^{2+}$, PKA or AKT signaling pathways, particularly stimulates duodenal mucosal $\mathrm{HCO}_{3}^{-}$secretion via $\mathrm{CFTR}$ and $\mathrm{Cl}^{-} / \mathrm{HCO}_{3}{ }^{-}$anion exchanger to protect duodenal mucosa. E2, Estrogen; ER, Estrogen receptor; PGE2, Prostaglandin E2; CFTR, cystic fibrosis transmembrane conductance regulator; $\mathrm{AE}, \mathrm{Cl}^{-} / \mathrm{HCO}_{3}{ }^{-}$anion exchanger; cAMP, cyclic adenosine monophosphate; PI3K, phosphatidylinositol 3-kinase; IP3R, Inositol 1,4,5-trisphosphate receptor 
ER $\beta$ direct and mediated antioxidant mechanisms, where both ER subtypes play equal and efficient roles in the antiinflammatory action of estrogen, in limiting the migration of neutrophils to the inflamed tissue, reducing the release and activation of cytokines and thereby alleviating tissue damage.

Another clinical implication is the protective effects of estrogen/estrogen receptors in GI disease by hormone replacement therapy (HRT). HRT after menopause was shown to be protective of disease activity in women with IBD, making them less likely to experience a flare of their disease [100]. A study suggests that menopausal hormone therapy users are at a decreased risk of esophageal and gastric adenocarcinoma and also of esophageal squamous cell carcinoma [101]. A large number of preclinical studies show that the expression of the ER $\beta$ has an inverse relation of the presence of colorectal polyps and tumors stage, and can mediate a protective response [102].

Genistein is an isoflavone phytestrogen produced naturally in a number of soy products such as soybeans, soy milk, soy flour, and tofu [85], it is structurally related to E2, and has been shown to bind to ER [86]. Recently, genistein is associated with a series of potential health benefits, including the decrease of women bone loss, reduction of clinical symptoms of diabetes and obesity, as well as lower risk of cardiovascular disease, prostate and breast cancer [85, 87-90]. Genistein has also been reported to regulate the functions of many ion transporters, including the $\mathrm{Na}^{+}-\mathrm{K}^{+}-2 \mathrm{Cl}^{-}$cotransporter [94], CFTR [91, 92], and the $\mathrm{K}^{+}$channels [93]. Although genistein stimulates duodenal mucosal $\mathrm{HCO}_{3}^{-}$and $\mathrm{Cl}^{-}$secretion by activating the CFTR channels, the activation of the $\mathrm{HCO}_{3}{ }^{-}$and $\mathrm{Cl}^{-}$secretion of CFTR channels in the duodenal epithelium are different. Since we have demonstrated that genistein is a greater activator of CFTR $\mathrm{HCO}_{3}^{-}$ conductance than $\mathrm{Cl}^{-}$conductance [95], we therefore propose that it could be clinically used for human GI epithelial protection. Additionally, genistein is promising pharmacotherapeutic for cystic fibrosis by modulating of ion transporters involved in the $\mathrm{Cl}^{-}$and $\mathrm{HCO}_{3}{ }^{-}$secretion of specific epithelial tissues [91, 92, 96].

Gender differences in gastrointestinal motility are known in state of health and disease, likely due to the effects of female hormones. Estrogen and progesterone receptors are found throughout the GI tract and may affect its motility [97]. Men have increased stomach acid production and more physiologic gastro-esophageal reflux than women [98]. All these sex differences may affect diagnostic parameters and therapeutic strategies of upper GI dysmotility. And it was also reported that estrogen receptor ligands modulate colonic motility and visceral pain [99].

As discussed earlier, since estrogen physiologically potentiates duodenal mucosal $\mathrm{HCO}_{3}^{-}$secretion, it may play an important role in the protection of GI mucosa against acid-induced injury. In distal colonic crypts, estrogen inhibits epithelial $\mathrm{Cl}^{-}$secretion in the female colon, which may prevent diarrhea. It was generally thought the regulatory mechanisms of $\mathrm{HCO}_{3}^{-}$and $\mathrm{Cl}^{-}$ secretion in GI tract are very similar. However, our study with others revealed that estrogen regulation of GI epithelial $\mathrm{HCO}_{3}^{-}$and $\mathrm{Cl}^{-}$secretion is obviously different, which stimulates epithelial $\mathrm{HCO}_{3}^{-}$secretion but inhibits $\mathrm{Cl}^{-}$secretion. Although the detailed underlying mechanisms need further investigation, the unique roles of estrogen in GI protection and diarrhea prevention may indicate a new perspective for pharmacotherapeutic development.

\section{CONCLUSIONS}

Previously, the interaction between organs have been reported between the reproductive system and urinary, intestinal systems [103]. However, the GI has not been considered as a sex-steroid targeted organ. The identification of functional ER in GI indicates the physiological roles of estrogen and ER in this system [78]. We demonstrated for the first time that estrogen regulation of duodenal mucosal $\mathrm{HCO}_{3}^{-}$secretion may contribute to the protection of duodenal mucosa from acid-induced damage and reducing the risk of duodenal ulcer formation. However, in the colon, E2 can decrease $\mathrm{Cl}^{-}$secretion. The unique roles of estrogen in GI protection and diarrhea prevention may be beneficial for potential pharmacotherapeutic development. HRT by using genistein might have a favorable effect on GI mucosal protection. Further study of estrogen/ERs in the digestive system could yield novel targets for the prevention and treatment of GI disease.

\section{Abbreviations}

GI, gastrointestinal; PI3K, phosphatidylinositol 3-kinase; CFTR, the cystic fibrosis transmembrane conductance regulator; CA, carbonic anhydrase; IBD, inflammatory bowel disease; PKA, protein kinase A; HRT, hormone replacement therapy; PGE2, Prostaglandin E2

\section{CONFLICTS OF INTEREST}

We have no conflicts of interest to declare.

\section{REFERENCES}

1. Lantz JM, Fullerton JT, Harshburger RJ, Sadler GR. Promoting screening and early detection of cancer in men. Nurs Health Sci. 2001; 3:189-196.

2. Williams DR. The health of men: structured inequalities and opportunities. Am J Public Health. 2003; 93:724-731.

3. Preedy JR, Aitken EH. The effect of estrogen on water and electrolyte metabolism. I. The normal. J Clin Invest. 1956; 35:423-429. 
4. Dignam WS, Voskian J, Assali NS. Effects of estrogens on renal hemodynamics and excretion of electrolytes in human subjects. J Clin Endocrinol Metab. 1956; 16:1032-1042.

5. Johnson JA, Davis JO. The effect of estrogens on renal sodium excretion in the dog. Perspect Nephrol Hypertens. 1976; 5:239-248.

6. Crocker AD. Variations in mucosal water and sodium transfer associated with the rat oestrous cycle. J Physiol. $1971 ; 214: 257-264$.

7. Zheng W, Shi M, You SE, Ji H, Roesch DM. Estrogens contribute to a sex difference in plasma potassium concentration: a mechanism for regulation of adrenal angiotensin receptors. Gend Med. 2006; 3:43-53.

8. Brunette MG, Leclerc M. Effect of estrogen on calcium and sodium transport by the nephron luminal membranes. J Endocrinol. 2001; 170:441-450.

9. Simpson ER. Sources of estrogen and their importance. J Steroid Biochem Mol Biol. 2003; 86:225-230.

10. Ascenzi P, Bocedi A, Marino M. Structure-function relationship of estrogen receptor alpha and beta: impact on human health. Mol Aspects Med. 2006; 27:299-402.

11. Fernandez SV, Russo J. Estrogen and xenoestrogens in breast cancer. Toxicol Pathol. 2010; 38:110-122.

12. Harvey BJ, Condliffe S, Doolan CM. Sex and salt hormones: rapid effects in epithelia. News Physiol Sci. 2001; 16:174-177.

13. O'Lone R, Frith MC, Karlsson EK, Hansen U. Genomic targets of nuclear estrogen receptors. Mol Endocrinol. 2004; 18:1859-1875.

14. Condliffe SB, Doolan CM, Harvey BJ. 17beta-oestradiol acutely regulates $\mathrm{Cl}$ - secretion in rat distal colonic epithelium. J Physiol. 2001; 530:47-54.

15. Raz L, Khan MM, Mahesh VB, Vadlamudi RK, Brann DW. Rapid estrogen signaling in the brain. Neurosignals. 2008; 16:140-153.

16. Xing D, Nozell S, Chen YF, Hage F, Oparil S. Estrogen and mechanisms of vascular protection. Arterioscler Thromb Vasc Biol. 2009; 29:289-295.

17. Moriarty K, Kim KH, Bender JR. Minireview: estrogen receptor-mediated rapid signaling. Endocrinology. 2006; 147:5557-5563.

18. Ueyama T, Shirasawa N, Numazawa M, Yamada K, Shelangouski M, Ito T, Tsuruo Y. Gastric parietal cells: potent endocrine role in secreting estrogen as a possible regulator of gastro-hepatic axis. Endocrinology. 2002; 143:3162-3170.

19. Ueyama T, Shirasawa N, Ito T, Tsuruo Y. Estrogenproducing steroidogenic pathways in parietal cells of the rat gastric mucosa. Life Sci. 2004; 74:2327-2337.

20. Gerhard M, Ganz P. How do we explain the clinical benefits of estrogen? From bedside to bench. Circulation. 1995; 92:5-8.

21. Grodstein F, Stampfer MJ, Manson JE, Colditz GA, Willett WC, Rosner B, Speizer FE, Hennekens CH.
Postmenopausal estrogen and progestin use and the risk of cardiovascular disease. N Engl J Med. 1996; 335:453-461.

22. Orshal JM, Khalil RA. Gender, sex hormones, and vascular tone. Am J Physiol Regul Integr Comp Physiol. 2004; 286:R233-249.

23. Zhang Y, Champagne N, Beitel LK, Goodyer CG, Trifiro M, LeBlanc A. Estrogen and androgen protection of human neurons against intracellular amyloid beta1-42 toxicity through heat shock protein 70. J Neurosci. 2004; 24:5315-5321.

24. Hurn PD, Macrae IM. Estrogen as a neuroprotectant in stroke. J Cereb Blood Flow Metab. 2000; 20:631-652.

25. Popp AW, Bodmer C, Senn C, Fuchs G, Kraenzlin ME, Wyss H, Birkhaeuser MH, Lippuner K. Prevention of postmenopausal bone loss with long-cycle hormone replacement therapy. Maturitas. 2006; 53:191-200.

26. Gozansky WS, Van Pelt RE, Jankowski CM, Schwartz RS, Kohrt WM. Protection of bone mass by estrogens and raloxifene during exercise-induced weight Loss. J Clin Endocrinol Metab. 2005; 90:52-59.

27. Yager JD, Davidson NE. Estrogen carcinogenesis in breast cancer. N Engl J Med. 2006; 354:270-282.

28. Giudice LC, Kao LC. Endometriosis. Lancet. 2004; 364:1789-1799.

29. Sipponen P, Varis K, Fraki O, Korri UM, Seppala K, Siurala M. Cumulative 10-year risk of symptomatic duodenal and gastric ulcer in patients with or without chronic gastritis. A clinical follow-up study of 454 outpatients. Scand J Gastroenterol. 1990; 25:966-973.

30. Schabowski J, Pitera J. Peptic ulcer among rural population in a selected region of south-eastern Poland. Ann Agric Environ Med. 2004; 11:323-327.

31. Dong WG, Cheng CS, Liu SP, Yu JP. Epidemiology of peptic ulcer disease in Wuhan area of China from 1997 to 2002. World J Gastroenterol. 2004; 10:3377-3379.

32. Wu HC, Tuo BG, Wu WM, Gao Y, Xu QQ, Zhao K. Prevalence of peptic ulcer in dyspeptic patients and the influence of age, sex, and Helicobacter pylori infection. Dig Dis Sci. 2008; 53:2650-2656.

33. Vessey MP, Villard-Mackintosh L, Painter R. Oral contraceptives and pregnancy in relation to peptic ulcer. Contraception. 1992; 46:349-357.

34. Bitton A, Peppercorn MA, Antonioli DA, Niles JL, Shah S, Bousvaros A, Ransil B, Wild G, Cohen A, Edwardes MD, Stevens AC. Clinical, biological, and histologic parameters as predictors of relapse in ulcerative colitis. Gastroenterology. 2001; 120:13-20.

35. Kuiper GG, Carlsson B, Grandien K, Enmark E, Haggblad J, Nilsson S, Gustafsson JA. Comparison of the ligand binding specificity and transcript tissue distribution of estrogen receptors alpha and beta. Endocrinology. 1997; 138:863-870.

36. Greene GL, Gilna P, Waterfield M, Baker A, Hort Y, Shine J. Sequence and expression of human estrogen receptor complementary DNA. Science. 1986; 231:1150-1154. 
37. Mosselman S, Polman J, Dijkema R. ER beta: identification and characterization of a novel human estrogen receptor. FEBS Lett. 1996; 392:49-53.

38. Saunders PT. Oestrogen receptor beta (ER beta). Rev Reprod. 1998; 3:164-171.

39. Pettersson K, Grandien K, Kuiper GG, Gustafsson JA. Mouse estrogen receptor beta forms estrogen response element-binding heterodimers with estrogen receptor alpha. Mol Endocrinol. 1997; 11:1486-1496.

40. Cowley SM, Hoare S, Mosselman S, Parker MG. Estrogen receptors alpha and beta form heterodimers on DNA. J Biol Chem. 1997; 272:19858-19862.

41. Thomas P, Pang Y, Filardo EJ, Dong J. Identity of an estrogen membrane receptor coupled to a $\mathrm{G}$ protein in human breast cancer cells. Endocrinology. 2005; 146:624-632.

42. Levin ER. G protein-coupled receptor 30: estrogen receptor or collaborator? Endocrinology. 2009; 150:1563-1565.

43. Revankar CM, Cimino DF, Sklar LA, Arterburn JB, Prossnitz ER. A transmembrane intracellular estrogen receptor mediates rapid cell signaling. Science. 2005; 307:1625-1630.

44. Shearer KE, Rickert EL, Peterson AC, Weatherman RV. Dissecting rapid estrogen signaling with conjugates. Steroids. 2012; 77:968-973.

45. Gustafsson JA. Estrogen receptor beta--a new dimension in estrogen mechanism of action. J Endocrinol. 1999; 163:379-383.

46. Hall JM, Couse JF, Korach KS. The multifaceted mechanisms of estradiol and estrogen receptor signaling. J Biol Chem. 2001; 276:36869-36872.

47. Gan L, He J, Zhang X, Zhang YJ, Yu GZ, Chen Y, Pan J, Wang JJ, Wang X. Expression profile and prognostic role of sex hormone receptors in gastric cancer. BMC Cancer. 2012; 12:566.

48. Zhou F, Xu Y, Shi J, Lan X, Zou X, Wang L, Huang Q. Expression profile of E-cadherin, estrogen receptors, and P53 in early-onset gastric cancers. Cancer Med. 2016; 5:3403-11.

49. Tuo B, Wen G, Wei J, Liu X, Wang X, Zhang Y, Wu H, Dong X, Chow JY, Vallon V, Dong H. Estrogen regulation of duodenal bicarbonate secretion and sex-specific protection of human duodenum. Gastroenterology. 2011; 141:854-863.

50. Harris HA, Bapat AR, Gonder DS, Frail DE. The ligand binding profiles of estrogen receptors alpha and beta are species dependent. Steroids. 2002; 67:379-384.

51. Jefferson WN, Padilla-Banks E, Clark G, Newbold RR. Assessing estrogenic activity of phytochemicals using transcriptional activation and immature mouse uterotrophic responses. J Chromatogr B Analyt Technol Biomed Life Sci. 2002; 777:179-189.

52. Harris HA, Katzenellenbogen JA, Katzenellenbogen BS. Characterization of the biological roles of the estrogen receptors, ERalpha and ERbeta, in estrogen target tissues in vivo through the use of an ERalpha-selective ligand. Endocrinology. 2002; 143:4172-4177.
53. Mewshaw RE, Edsall RJ Jr, Yang C, Manas ES, $\mathrm{Xu} \mathrm{ZB}$, Henderson RA, Keith JC Jr, Harris HA. ERbeta ligands. 3. Exploiting two binding orientations of the 2-phenylnaphthalene scaffold to achieve ERbeta selectivity. J Med Chem. 2005; 48:3953-3979.

54. Harris HA, Albert LM, Leathurby Y, Malamas MS, Mewshaw RE, Miller CP, Kharode YP, Marzolf J, Komm BS, Winneker RC, Frail DE, Henderson RA, Zhu Y, Keith JC Jr. Evaluation of an estrogen receptor-beta agonist in animal models of human disease. Endocrinology. 2003; 144:4241-4249.

55. Kumral ZN, Memi G, Ercan F, Yegen BC. Estrogen alleviates acetic acid-induced gastric or colonic damage via both ERalpha- and ERbeta-mediated and direct antioxidant mechanisms in rats. Inflammation. 2014; 37:694-705.

56. Seidler U. Acta Physiologica symposium: acid-base transporters and epithelial electrolyte transport. Acta Physiol (Oxf). 2011; 201:1-2.

57. Flemstrom G, Kivilaakso E. Demonstration of a $\mathrm{pH}$ gradient at the luminal surface of rat duodenum in vivo and its dependence on mucosal alkaline secretion. Gastroenterology. 1983; 84:787-794.

58. Takeuchi K, Magee D, Critchlow J, Matthews J, Silen W. Studies of the $\mathrm{pH}$ gradient and thickness of frog gastric mucus gel. Gastroenterology. 1983; 84:331-340.

59. Williams SE, Turnberg LA. Demonstration of a $\mathrm{pH}$ gradient across mucus adherent to rabbit gastric mucosa: evidence for a 'mucus-bicarbonate' barrier. Gut. 1981; 22:94-96.

60. Flemstrom G. Active alkalinization by amphibian gastric fundic mucosa in vitro. Am J Physiol. 1977; 233:E1-12.

61. Graper WP, Crass RA, Halpern NB, Fromm D, Silen W. Secretion of base by the in vitro amphibian antrum. Surg Forum. 1976; 27:435-437.

62. Flemstrom G. Stimulation of $\mathrm{HCO} 3-$ transport in isolated proximal bullfrog duodenum by prostaglandins. Am J Physiol. 1980; 239:G198-203.

63. Flemstrom G, Isenberg JI. Gastroduodenal mucosal alkaline secretion and mucosal protection. News Physiol Sci. 2001; 16:23-28.

64. Allen A, Flemstrom G. Gastroduodenal mucus bicarbonate barrier: protection against acid and pepsin. Am J Physiol Cell Physiol. 2005; 288:C1-19.

65. Isenberg JI, Selling JA, Hogan DL, Koss MA. Impaired proximal duodenal mucosal bicarbonate secretion in patients with duodenal ulcer. N Engl J Med. 1987; 316:374-379.

66. Kurata JH, Honda GD, Frankl H. The incidence of duodenal and gastric ulcers in a large health maintenance organization. Am J Public Health. 1985; 75:625-629.

67. Rosenstock SJ, Jorgensen T. Prevalence and incidence of peptic ulcer disease in a Danish County--a prospective cohort study. Gut. 1995; 36:819-824.

68. Aguwa CN. Effects of exogenous administration of female sex hormones on gastric secretion and ulcer formation in the rat. Eur J Pharmacol. 1984; 104:79-84. 
69. Shimozawa N, Okajima K, Harada N, Arai M, Ishida Y, Shimada S, Kurihara H, Nakagata N. Contribution of sensory neurons to sex difference in the development of stress-induced gastric mucosal injury in mice. Gastroenterology. 2006; 131:1826-1834.

70. Smith A, Contreras C, Ko KH, Chow J, Dong X, Tuo B, Zhang HH, Chen DB, Dong H. Gender-specific protection of estrogen against gastric acid-induced duodenal injury: stimulation of duodenal mucosal bicarbonate secretion. Endocrinology. 2008; 149:4554-4566.

71. Crofford LJ. Prostaglandin biology. Gastroenterol Clin North Am. 2001; 30:863-876.

72. Smith WL. Prostanoid biosynthesis and mechanisms of action. Am J Physiol. 1992; 263:F181-191.

73. Cryer B. Mucosal defense and repair. Role of prostaglandins in the stomach and duodenum. Gastroenterol Clin North Am. 2001; 30:877-894, v-vi.

74. Takeuchi K, Yagi K, Kato S, Ukawa H. Roles of prostaglandin E-receptor subtypes in gastric and duodenal bicarbonate secretion in rats. Gastroenterology. 1997; 113:1553-1559.

75. Rajagopal M, Thomas SV, Kathpalia PP, Chen Y, Pao AC. Prostaglandin E2 induces chloride secretion through crosstalk between cAMP and calcium signaling in mouse inner medullary collecting duct cells. Am J Physiol Cell Physiol. 2014; 306:C263-278.

76. Tuo B, Wen G, Wang X, Xu J, Xie R, Liu X, Dong H. Estrogen potentiates prostaglandin $\mathrm{E}(2)$-stimulated duodenal mucosal $\mathrm{HCO}(3)(-)$ secretion in mice. Am J Physiol Endocrinol Metab. 2012; 303:E111-121.

77. Karim K, Giribabu N, Muniandy S, Salleh N. Estrogen and progesterone differentially regulate carbonic anhydrase II, III, IX, XII, and XIII in ovariectomized rat uteri. Syst Biol Reprod Med. 2016; 62:57-68.

78. Thomas ML, Xu X, Norfleet AM, Watson CS. The presence of functional estrogen receptors in intestinal epithelial cells. Endocrinology. 1993; 132:426-430.

79. Alzamora R, O’Mahony F, Bustos V, Rapetti-Mauss R, Urbach V, Cid LP, Sepulveda FV, Harvey BJ. Sexual dimorphism and oestrogen regulation of KCNE3 expression modulates the functional properties of KCNQ1 $\mathrm{K}(+)$ channels. J Physiol. 2011; 589:5091-5107.

80. Alzamora R, O’Mahony F, Harvey BJ. Estrogen inhibits chloride secretion caused by cholera and Escherichia coli enterotoxins in female rat distal colon. Steroids. 2011; 76:867-876.

81. Rapetti-Mauss R, O'Mahony F, Sepulveda FV, Urbach V, Harvey BJ. Oestrogen promotes KCNQ1 potassium channel endocytosis and postendocytic trafficking in colonic epithelium. J Physiol. 2013; 591:2813-2831.

82. O'Mahony F, Thomas W, Harvey BJ. Novel female sexdependent actions of oestrogen in the intestine. J Physiol. 2009; 587:5039-5044.
83. O'Mahony F, Harvey BJ. Sex and estrous cycle-dependent rapid protein kinase signaling actions of estrogen in distal colonic cells. Steroids. 2008; 73:889-894.

84. Saint-Criq V, Rapetti-Mauss R, Yusef YR, Harvey BJ. Estrogen regulation of epithelial ion transport: Implications in health and disease. Steroids. 2012; 77:918-923.

85. Bhathena SJ, Velasquez MT. Beneficial role of dietary phytoestrogens in obesity and diabetes. Am J Clin Nutr. 2002; 76:1191-1201.

86. Kuiper GG, Lemmen JG, Carlsson B, Corton JC, Safe SH, van der Saag PT, van der Burg B, Gustafsson JA. Interaction of estrogenic chemicals and phytoestrogens with estrogen receptor beta. Endocrinology. 1998; 139:4252-4263.

87. Atteritano M, Mazzaferro S, Frisina A, Cannata ML, Bitto A, D’Anna R, Squadrito F, Macri I, Frisina N, Buemi M. Genistein effects on quantitative ultrasound parameters and bone mineral density in osteopenic postmenopausal women. Osteoporos Int. 2009; 20:1947-1954.

88. Duffy C, Perez K, Partridge A. Implications of phytoestrogen intake for breast cancer. CA Cancer J Clin. 2007; 57:260-277.

89. Konturek PC, Konturek SJ, Hahn EG. Duodenal alkaline secretion: its mechanisms and role in mucosal protection against gastric acid. Dig Liver Dis. 2004; 36:505-512.

90. Lichtenstein AH. Soy protein, isoflavones and cardiovascular disease risk. J Nutr. 1998; 128:1589-1592.

91. Al-Nakkash L, Springsteel MF, Kurth MJ, Nantz MH. Activation of CFTR by UCCF-029 and genistein. Bioorg Med Chem Lett. 2008; 18:3874-3877.

92. Schmidt A, Hughes LK, Cai Z, Mendes F, Li H, Sheppard DN, Amaral MD. Prolonged treatment of cells with genistein modulates the expression and function of the cystic fibrosis transmembrane conductance regulator. Br J Pharmacol. 2008; 153:1311-1323.

93. Hirsch J, Schlatter E. Genistein potentiates the ANP effect on a $\mathrm{K}(+)$-conductance in HEK-293 cells. Cell Physiol Biochem. 2003; 13:223-228.

94. Niisato N, Ito Y, Marunaka Y. Activation of Cl- channel and $\mathrm{Na}+/ \mathrm{K}+/ 2 \mathrm{Cl}-$ cotransporter in renal epithelial A6 cells by flavonoids: genistein, daidzein, and apigenin. Biochem Biophys Res Commun. 1999; 254:368-371.

95. Tuo B, Wen G, Seidler U. Differential activation of the $\mathrm{HCO}(-)$ conductance through the cystic fibrosis transmembrane conductance regulator anion channel by genistein and forskolin in murine duodenum. $\mathrm{Br} \mathrm{J}$ Pharmacol. 2009; 158:1313-1321.

96. Roomans GM. Pharmacological treatment of the ion transport defect in cystic fibrosis. Expert Opin Investig Drugs. 2001; 10:1-19.

97. Zia JK, Heitkemper MM. Upper Gastrointestinal Tract Motility Disorders in Women, Gastroparesis, and Gastroesophageal Reflux Disease. Gastroenterol Clin North Am. 2016; 45:239-251. 
98. Ter RB. Gender differences in gastroesophageal reflux disease. The journal of gender-specific medicine : JGSM : the official journal of the Partnership for Women's Health at Columbia. 2000; 3:42-44.

99. Zielinska M, Fichna J, Bashashati M, Habibi S, Sibaev A, Timmermans JP, Storr M. G protein-coupled estrogen receptor and estrogen receptor ligands regulate colonic motility and visceral pain. Neurogastroenterol Motil. 2017.

100. Kane SV, Reddy D. Hormonal replacement therapy after menopause is protective of disease activity in women with inflammatory bowel disease. Am J Gastroenterol. 2008; 103:1193-1196.
101. Brusselaers N, Maret-Ouda J, Konings P, El-Serag HB, Lagergren J. Menopausal hormone therapy and the risk of esophageal and gastric cancer. Int J Cancer. 2017; 140:1693-1699.

102. Williams C, DiLeo A, Niv Y, Gustafsson JA. Estrogen receptor beta as target for colorectal cancer prevention. Cancer Lett. 2016; 372:48-56.

103. Nelson HD, Humphrey LL, Nygren P, Teutsch SM, Allan JD. Postmenopausal hormone replacement therapy: scientific review. JAMA. 2002; 288:872-881. 